\title{
New records of Bentharca asperula (Dall, 1881) (Mollusca, Bivalvia, Arcidae) from Brazil
}

\author{
Flávio Dias Passos ${ }^{1,3}$ \& Adolpho Birman ${ }^{2}$ \\ ${ }^{1}$ Departamento de Biologia Animal, Instituto de Biologia, \\ Universidade Estadual de Campinas - UNICAMP, \\ CP 6109, CEP 13083-970, Campinas, SP, Brazil \\ ${ }^{2}$ Rua Gabriel dos Santos, 168, apto. 51A, CEP 01231-010, São Paulo, SP, Brazil \\ ${ }^{3}$ Corresponding author: Flávio Dias Passos, e-mail: flaviodp@unicamp.br
}

PASSOS, F.D. \& BIRMAN, A. New records of Bentharca asperula (Dall, 1881) (Mollusca, Bivalvia, Arcidae) from Brazil. Biota Neotrop., 9(4): http://www.biotaneotropica.org.br/v9n4/en/abstract?shortcommunication+bn02309042009.

\begin{abstract}
Specimens of Bentharca asperula (Dall, 1881) were obtained from deep waters of the coasts of the Rio de Janeiro and São Paulo States, and their shells described, illustrated and compared with descriptions and illustrations obtained from the literature. This species has a small strongly inequilateral shell, trapezoidal in outline and expanded ventro-posteriorly; their umbos are placed at about 1/3 of the anterior length of their straight hinge line. The external sculpture consists of irregular spaced concentric ridges, intercepted by fine radiating striae; the periostracum is hairy, forming a cover as a thatch. Hinge teeth are small, disposed in two series interrupted by the ligament. With this finding of living specimens from the Bacia de Campos, the distribution of B. asperula can now be extended in the Brazilian coast, confirming its wide spread in the Atlantic Ocean.
\end{abstract}

Keywords: Bentharca asperula, Brazil, Arcidae, Bivalvia, Mollusca.

PASSOS, F.D. \& BIRMAN, A. Novos registros de Bentharca asperula (Dall, 1881) (Mollusca, Bivalvia, Arcidae) para o Brasil. Biota Neotrop., 9(4): http://www.biotaneotropica.org.br/v9n4/pt/abstract?shortcommunication+bn02309042009.

Resumo: Espécimes de Bentharca asperula (Dall, 1881) foram obtidos em águas profundas da costa dos Estados de Rio de Janeiro e São Paulo, e suas conchas descritas, ilustradas e comparadas com descrições e ilustrações obtidas da literatura. A espécie possui concha pequena, fortemente inequilateral, com valvas de contorno trapezoidal e expandidas ventro-posteriormente; os umbos são localizados aproximadamente no terço anterior do comprimento da linha da charneira, que é reta. A escultura externa consiste de linhas concêntricas, irregularmente espaçadas, interceptadas por estrias radiais finas; o perióstraco é piloso, formando uma cobertura semelhante a sapé. Os dentes da charneira são pequenos, dispostos em duas séries interrompidas pelo ligamento. Com este registro feito a partir de espécimes vivos provenientes da Bacia de Campos, a distribuição geográfica de $B$. asperula pode ser então estendida na costa brasileira, confirmando sua larga ocorrência no Oceano Atlântico.

Palavras-chave: Bentharca asperula, Brasil, Arcidae, Bivalvia, Mollusca. 


\section{Introduction}

The Brazilian coast bears a rich benthonic fauna, from where the representative species of shallow waters are relatively well studied while those from deep waters can be considered poorly known. For the Bivalvia (Mollusca), in particular, recent works suggest that there are many new species to be recorded from deep waters, most of them characterized by their small shells (Absalão et al. 2003, Oliveira \& Absalão 2007, Oliveira \& Absalão 2008). Deep water Arcidae Lamarck, 1809 can be considered examples of these bivalves. Twelve species of this family are known from the Brazilian coast (Rios 1994), most of them from shallow depths. With recent dredging of bottoms from the continental slope and oceanic islands other species have been discovered, such as Bathyarca pectunculoides (Scacchi, 1834) from the States of Rio de Janeiro and São Paulo (Absalão et al. 2003, Amaral et al. 2006), and Acar transmar Simone, 2009 described from the São Pedro and São Paulo Archipelago (Simone 2009). Prado \& Nascimento (1994) registered the occurrence of Bentharca asperula (Dall, 1881) from the State of Pernambuco
( $8{ }^{\circ} 50^{\prime}$ 5" $\mathrm{S}$ and $33^{\circ} 39^{\prime} 5^{\prime \prime} \mathrm{W}$; at $4633 \mathrm{~m}$ depth), northeastern Brazil, but their description was very poor and based on only two valves. In this paper we present a new evidence of the presence of this latter species in Brazil, and describe their shells in detail.

\section{Material and Methods}

The examined specimens of B. asperula were obtained from two different regions of the southeastern coast of Brazil. In June 1971, two whole shells and ten isolated valves were obtained with a mean bean trawl at a depth of 3,049 m in the coast of São Paulo State, by the Research Vessel "Prof. W. Besnard" of the Universidade de São Paulo; part of this material is deposited in the molluscan collections of the "Museu de Zoologia da Universidade de São Paulo" (MZUSP) and of the "Museu de Zoologia da Universidade Estadual de Campinas 'Prof. Adão José Cardoso"' (ZUEC BIV). These shells are the most well preserved, one of them with the valves united and with byssus threads still present; they were photographed and their protoconch measured through a Zeiss

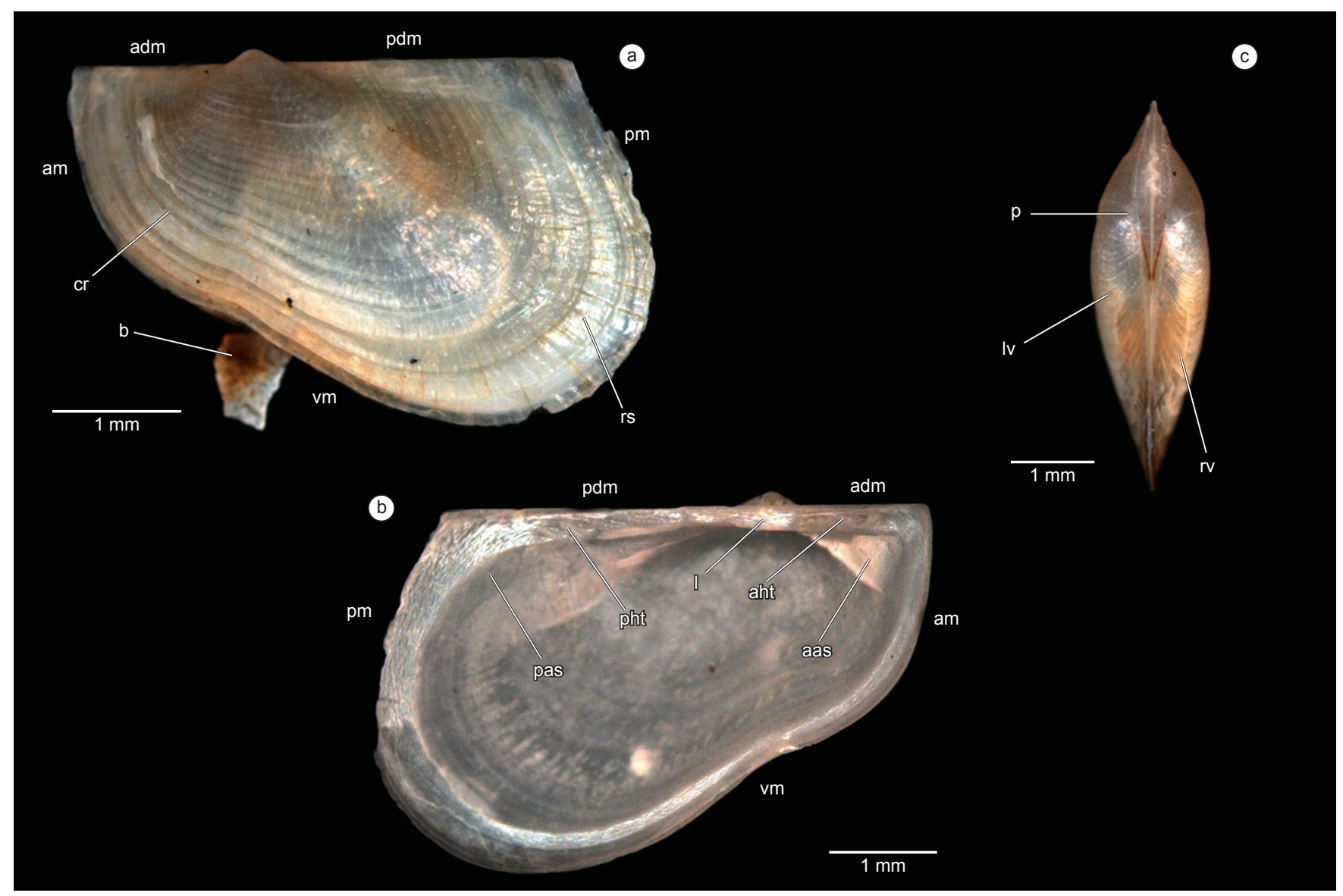

Figure 1. Bentharca asperula (Dall, 1881). (a = External view from the left side of specimen labeled "MZUSP 90934", b = Internal view of the left valve of specimen labeled "ZUEC BIV 1466", c = Dorsal view of the specimen of the Figure 1a); In a the byssus is still present and attached to a small particle; aas $=$ anterior adductor muscle scar; $\mathrm{adm}=$ anterior dorsal margin; $\mathrm{aht}=$ anterior hinge teeth; $\mathrm{am}=$ anterior margin; $\mathrm{b}=$ byssus; $\mathrm{cr}=\mathrm{concentric}$ ridge $; \mathrm{l}=$ ligament; lv = left valve; $\mathrm{p}=$ prodissoconch; pas = posterior adductor muscle scar; $\mathrm{pdm}=$ posterior dorsal margin; pht $=$ posterior hinge teeth; $\mathrm{pm}=$ posterior margin; $\mathrm{rs}=$ radial striae; $\mathrm{rv}=$ right valve; $\mathrm{vm}=$ ventral margin .

Figura 1. Bentharca asperula (Dall, 1881). (A = Vista externa do lado esquerdo do espécime "MZUSP 90934", B = Vista interna da valva esquerda do espécime "ZUEC BIV 1466", C = Vista dorsal do espécime da Figura 1A); Em A o bisso ainda está presente e fixo a uma pequena partícula; aas = cicatriz do músculo adutor anterior; $\mathrm{adm}=$ margem dorsal anterior; $\mathrm{aht}=$ dentes anteriores da charneira; $\mathrm{am}=$ margem anterior; $\mathrm{b}=$ bisso; $\mathrm{cr}=$ estria concêntrica; $1=$ ligamento; $\mathrm{l}=$ valva esquerda; $\mathrm{p}=$ prodissoconcha; $\mathrm{pas}=$ cicatriz do músculo adutor posterior; $\mathrm{pdm}=$ margem dorsal posterior; pht = dentes posteriores da charneira; $\mathrm{pm}=$ margem posterior; $\mathrm{rs}=$ estria radial; $\mathrm{rv}=$ valva direita; $\mathrm{vm}=$ margem ventral . 
STEMI 2000 Stereomicroscope. Sixty other isolated valves were also obtained with box corers in 2001, 2002 and 2003, by the Research Vessel "Astro-Garoupa" of Petrobras S.A. (an oil company of Brazil) at depths between 1670 to $1972 \mathrm{~m}$ in the Bacia de Campos off the Rio de Janeiro coast; they are all in the molluscan collection of the "Instituto de Biologia da Universidade Federal do Rio de Janeiro" (IBUFRJ). All shells were compared with those described and illustrated in the literature, particularly Knudsen $(1967,1970)$ and Oliver \& Allen (1980), who had analyzed typespecimens. The specimen in which the byssus threads were still present was maintained in $70 \%$ ethanol; the other ones were dried.

\section{Results}

Bivalvia Linnaeus, 1758

Arcidae Lamarck, 1809

Bentharca Thiele, 1931

Bentharca asperula (Dall, 1881)

Material examined: IBUFRJ 12920 (22 5' 39" S and 39॰ 46' 00" W, 1730 m), 09.V.2002, [1 valve]; IBUFRJ 12897 (22 6' 46" S and 39 44' 18' W, $1930 \mathrm{~m}), 08 . \mathrm{V} .2002$, [2 valves];

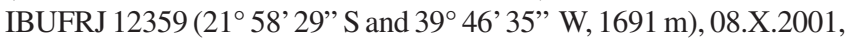
[1 valve]; IBUFRJ 12358 (20 27.71' $\mathrm{S}$ and $\left.39^{\circ} 38.11^{\prime} \mathrm{W}, 1680 \mathrm{~m}\right)$, 15.VII.2001, [2 valves]; MZUSP 90934 (24 $12^{\prime} \mathrm{S}$ and 40 $23^{\prime} \mathrm{W}$, $3049 \mathrm{~m}$ ), 01.VI.1971, [1 shell with the valves still articulated and the byssus present]; MZUSP 90935 (24 $12^{\prime}$ S and 40 23' W, $3049 \mathrm{~m}$ ), 01.VI.1971, [4 valves]; ZUEC BIV 1466 (24 ${ }^{\circ} 12^{\prime} \mathrm{S}$ and $40^{\circ} 23^{\prime}$ W, $3049 \mathrm{~m}$ ), 01.VI.1971, (two valves from the same specimen); ZUEC BIV 1467 (24 $12^{\prime} \mathrm{S}$ and 40 23' W, $3049 \mathrm{~m}$ ), 01.VI.1971, (6 valves).

Description: Shell small, larger examined specimen with $8.4 \mathrm{~mm}$ of shell length; $\mathrm{L} / \mathrm{H}=1.6, \mathrm{~L} / \mathrm{W}=3.2$; white, strongly inequilateral, trapezoidal in outline, expanded ventro-posteriorly (Figure 1a); thin and semitransparent in small specimens. Inequivalve, moderately inflated, with the ventral margin of the left valve slightly overlapping the right one; byssal notch present as a small groove. Umbos moderately inflated, orthogirate, slightly projected dorsally and placed at about $1 / 3$ of the anterior length of the hinge line (Figures 1a, b). Prodissoconch D-shaped, about $250 \mu \mathrm{m}$ in length (Figure 1c). Anterior and posterior dorsal margins straight, marked off from the anterior and posterior margins (Figure 1a). Anterior margin straight; posterior margin nearly straight in its dorsal part and rounded in its ventral part. Ventral margin sinuous by the presence of the byssal notch at its anterior third, and rounded uniformly in the confluence with the anterior and posterior margins. Shallow sulcus present in the external surface, running almost vertically from the umbo to the ventral margin of the shell. Sculpture consisted of irregular spaced concentric ridges, rather distinct in larger specimens, intercepted by fine radiating striae. Periostracum thin, brownish, transparent, only visible in well preserved specimens, adhered, hairy and forming a cover as a thatch; extending beyond the margin of the valves, particularly at their ventro-posterior margins. Hinge long, straight, narrow, with a more shortened plate below and just posterior to the umbo (Figure 1c). Hinge teeth small, disposed in two series interrupted by the ligament; the anterior series with 3 to 6 sub-vertical teeth, the posterior with 3 to 6 oblique teeth. Ligament short, formed by laminae parallel to the hinge line, positioned below and slightly posterior to the umbones. Internal surface of the valves white, bright, with smooth anterior, ventral and posterior margins. Anterior adductor muscle scar small, rounded; posterior adductor muscle scar large, rounded. Retractor muscle scars not visible.

\section{Discussion}

Knudsen $(1967,1970)$ considered Bentharca Thiele, 1931 a synonym of Acar Gray, 1857, an opinion not accepted by Oliver \& Allen (1980), who preferred to separate all Bentharca species from other shallow water Arcidae. Bentharca is similar to Bathyarca Kobelt, 1891, another genus of this same family from the deep-sea. However, the valves are rounded in outline in those species of the latest genus while in Bentharca it is trapezoidal. Oliver \& Allen (1980) considered that there are probably no more than three valid species of Bentharca, one of them being B. asperula. The examined specimens from the Brazilian coast are identical to those of this species described and illustrated by Knudsen $(1967,1970)$ and Oliver \& Allen (1980), who noted variations in some of its conchiliological characters (as shell shape and dentition), mainly related to the shell size. The illustration furnished by Prado \& Nascimento (1994) (both shell dealers) is a copy of the Figure 4993 of Abbott (1974, page 424) and so do not permit a comparison with other specimens collected from off Brazil. A list of synonyms of B. asperula can be obtained in Knudsen $(1967,1970)$ and Oliver \& Allen (1980). Aspects of its biology and anatomy are described by Knudsen (1970) and Oliver \& Allen (1980), respectively.

This finding of well preserved specimens of $B$. asperula from the coast of Rio de Janeiro and São Paulo, one of them with the byssus threads still present, confirms its occurrence in the place of collection. B. asperula has been recorded from all oceans (except from the Arctic and Antarctic), with a wide bathymetric distribution, from 430 to $5007 \mathrm{~m}$ (Knudsen 1970). Until now, however, apart from the record of Prado \& Nascimento (1994), this species was not known for the southeast coast of the Americas. So, with the occurrence of living specimens in the Bacia de Campos, its distribution can now be extended in the Brazilian coast, confirming its wide spread distribution in the Atlantic Ocean.

\section{Acknowledgements}

Our special thanks are due to Prof. Dr. Ricardo Silva Absalão, Universidade Federal do Rio de Janeiro, for the loan of specimens deposited in the molluscan collection of that institution; and to André Fernando Sartori, University of Cambridge, who kindly provided bibliographic material.

\section{References}

ABBOTT, R.T. 1974. American Seashells. 2 ed. Van Nostrand Reinhold Co., New York.

ABSALÃO, R.S., CAETANO, C.H.S. \& PIMENTA, A.D. 2003. Novas ocorrências de gastrópodes e bivalves marinhos do Brasil (Mollusca). Rev. Bras. de Zool. 20(2):323-328.

AMARAL, A.C.Z., RIZZO, A.E. \& ARRUDA, E.P. 2006. Manual de identificação dos invertebrados marinhos da região sudeste-sul do Brasil. Editora USP São Paulo.

KNUDSEN, J. 1967. The deep sea Bivalvia. Scient. Rep. John Murray Exped. $11: 235-343$

KNUDSEN, J. 1970. The systematics and biology of abyssal and hadal Bivalvia. Galathea Rep. 11:7-241

OLIVEIRA, C.D.C. \& ABSALÃO, R.S. 2007. Primeiro registro de Mendicula ferruginosa, Kelliella atlantica e Lyonsiella subquadrata (Mollusca, Pelecypoda) para águas brasileiras. Biociências 15(1):63-67.

OLIVEIRA, C.D.C. \& ABSALÃO, R.S. 2008. The genera Limatula and Limea (Mollusca, Pelecypoda, Limidae) from deep waters off Brazil. Zootaxa 1940:48-58.

OLIVER, G. \& ALLEN, J.A. 1980. The functional and adaptive morphology of the deep-sea species of the Arcacea (Mollusca: Bivalvia) from the Atlantic. Phil. Trans. Roy. Soc. London, B, Biol. Sci. 291(1045):45-76.

PRADO, A.C.G. \& NASCIMENTO, J.C.B. 1994. Bentharca asperula (Dall, 1881) - Arcidae, Anadarinae - Nova ocorrência para a costa brasileira (Recife/ Pernambuco). Publ. Ocas. Conquil. Brasil 9:1-2.

RIOS, E.C. 1994. Seashells of Brazil. 2 ed. Museu Oceanográfico Prof. E. C. Rios da Fundação Universidade do Rio Grande, Rio Grande.

SIMONE, L.R.L. 2009. A new species of Acar (Bivalvia, Arcidae) from São Pedro e São Paulo Archipelago, Brazil. Novapex 10(1):9-16. 